\title{
Five hypotheses concerning the fate of the Singapore issues in the Doha Round
}

\author{
Simon J. Evenett*
}

\begin{abstract}
At the Cancún Ministerial Conference, the members of the World Trade Organization (WTO) disagreed on whether to launch negotiations on multilateral disciplines concerning the four areas of government policy collectively known as the 'Singapore issues'. This amounted to a decision not to expand the WTO's boundaries along these dimensions. In this paper, five hypotheses concerning the treatment of the Singapore issues by the WTO's membership are described and assessed. The implications of this assessment for the likelihood that, at some future date, similar proposals can be successfully advanced in the multilateral trade arena are also discussed.
\end{abstract}

Key words: WTO, Doha Round, Singapore issues

JEL classification: F13

\section{Introduction}

In many respects the Doha Round of multilateral trade negotiations has been curious. WTO members responded to acute geopolitical circumstances in the second half of 2001 and in an act of international solidarity launched the Doha Round. At that time WTO members were prepared to set an end date for the negotiations but not to finalize the contents of the negotiating agenda, effectively leaving undefined the potential negotiating trade-offs. Furthermore, the shadow of the past — not just in terms of the so-called 'built-in agenda', but also the concerns of some about the costs of implementing the Uruguay Round commitments-loomed heavily over the subsequent deliberations.

*University of St Gallen and CEPR, e-mail: simon.evenett@unisg.ch

My writings can be downloaded from www.evenett.com, where there is further contact information. I thank a number of current and former trade officials for discussing the fate of the Singapore issues with me. Comments and suggestions from Bernard Hoekman and David Vines were gratefully received. I alone bear responsibility for the contents of this paper and for any errors and omissions. doi: 10.1093/icb/grm025

(C) The Author 2007. Published by Oxford University Press.

For permissions please e-mail: journals.permissions@oxfordjournals.org 
One of the decisions that WTO members took collectively during the Doha Round was not to launch negotiations on three of the four so-called 'Singapore issues' (specifically, provisions relating to the interaction between trade and investment, the interaction between trade and competition policy, and transparency in government procurement practices). Moreover, WTO members decided not to undertake any further work on these three subjects for the duration of the Doha Round. In the so-called 'July 2004 package', WTO members also decided to launch negotiations on further trade facilitation measures. These decisions were taken just under a year after the Cancún Ministerial Conference collapsed in acrimony. Together, this Ministerial Conference and the July 2004 package formally sealed the fate of the Singapore issues in the Doha Round.

In this paper I examine the factors responsible for the fate of the Singapore issues in the early years of the Doha Round, bearing in mind that even the proposals to launch negotiations on trade facilitation were initially rejected by the African, Caribbean, and Pacific group of developing countries (the ACP countries) at the Cancún Ministerial Conference. I do not propose to examine here the relative merits of the various proposals for further multilateral disciplines on the Singapore issues; some former colleagues and I have already done so in considerable detail (see the chapters of SECO and Evenett (2003)). Nor do I propose to offer a blow-by-blow account of the run-up to and the events at the Cancún Ministerial Conference. ${ }^{1}$

Instead, I describe and evaluate five hypotheses concerning the Singapore issues' fate in the early years of the Doha Round. One hypothesis, namely that the WTO was the wrong institution to house these additional multilateral disciplines, is given particular attention. In doing so, I consider the small literature on the scope and boundaries of the WTO. This literature seeks to identify the considerations which determine the matters that can appropriately be bound in multilateral trade rules and enforced by the WTO's Dispute Settlement Understanding. But, as I show, the literature is not conclusive. I also discuss the implications of these five hypotheses for the likelihood that, at some future date, similar proposals can be successfully advanced in the multilateral trade arena.

The remainder of this paper is organized as follows. The next section briefly summarizes the history of the Singapore issues since the creation of the WTO in 1995, including the decisions taken by WTO members with respect to deliberations and possible negotiations on the four associated areas of government policy. The third section introduces and evaluates five hypotheses that might account for the fate of the Singapore issues. The fourth section recapitulates the goal and contents of the paper, and some concluding remarks are offered.

\section{A brief history of the Singapore issues since $1995^{2}$}

The purpose of this section is to describe the major decisions since the establishment of the WTO in 1995 pertaining to the deliberations of the WTO membership on the Singapore issues. The following account of these decisions, plus the circumstances that surround them, may help the reader to judge better the veracity of the five hypotheses concerning the fate of the Singapore issues that are described in the next section.

\footnotetext{
${ }^{1}$ For different accounts of what happened at the Cancún Ministerial Conference, see Ahmed (2003), Hoekman (2003), Khor (2003), and White \& Case (2003).

${ }^{2}$ An informative account of the treatment of the Singapore issues by the WTO membership through 2003 can be found in Federal Trust (2003)
} 
It may be useful to start by noting that the range of matters that fell within the Single Undertaking of the Doha Round of multilateral trade negotiations was not completely determined at its launch in November 2001. In different ways the legacy of the Uruguay Round, the previous multilateral trade round concluded in 1993, was to influence the items included in the Doha Round's Single Undertaking. First, there was the built-in agenda of (in the eyes of some WTO members) unfinished negotiations on agriculture and services and these were rolled into the Doha Round. Second, many developing countries were keen to see their concerns about the implementation of Uruguay Round agreements addressed seriously by the WTO membership before or during the Doha Round. ${ }^{3}$ On top of this were proposals, made principally by industrialized countries, to include negotiations on multilateral disciplines on investment policy, competition law and enforcement, transparency in government procurement practices, and trade facilitation. ${ }^{4}$ At the WTO Ministerial Conference in Singapore in 1996 it was decided to set up three working groups to address the first three of these matters and to ask the Council for Trade in Goods to examine the merits of further WTO disciplines on trade facilitation. These deliberations were not to be negotiations; a formal decision on whether to launch formal negotiations was to be taken at a later date. Rather, these initiatives were supposed to acquaint WTO members with the policies in question, to clarify existing multilateral disciplines (where appropriate), and to examine potential WTO disciplines in these areas; in short, a pre-negotiating study phase - at least, that was the hope of the proponents of the Singapore issues.

As a result of the collapse of the Seattle Ministerial Conference in 1999, the next major decision on the Singapore issues took place at the Doha Ministerial Conference in November 2001. Rocked by the attacks on New York City and on the Pentagon, policy-makers around the globe saw the need to demonstrate solidarity, and the opportunity was taken to launch a round of multilateral trade negotiations. The launch was not smooth because some developing countries insisted that a 'development agenda' be adopted for what was to become known as the Doha Round and that it was premature to launch formal negotiations on the Singapore issues. Some deft diplomatic footwork resulted in a Ministerial Declaration which stated that WTO members had decided to launch negotiations on each of the four Singapore issues; however, the modalities (international trade-speak for the precise terms) of the negotiations would be determined at the next WTO Ministerial Conference (that was to take place in Cancún, Mexico). The relevant bodies at the WTO deliberating on the Singapore issues were particularly active between the Doha and Cancún Ministerial Conferences (see SECO and Evenett, 2003). In Table $1 \mathrm{I}$ have listed the additional multilateral disciplines sought by the major proponents of each Singapore Issue. The European Communities and its member states (EC) were proponents of each Singapore issue. ${ }^{5}$ Korea and Japan supported negotiations

\footnotetext{
${ }^{3}$ For some time, several developing countries argued that it would be inappropriate to launch the Doha Round before the implementation matters arising from the Uruguay Round were resolved.

${ }^{4}$ During the period 1995-9, certain industrialized countries argued for multilateral disciplines on labour standards and on environmental policy to be negotiated. Developing countries were able successfully to resist negotiations of the former, and negotiations on the latter were confined to a modest range of matters. In some literature, especially that written before 1999 or dealing with the period up to 1999, the term 'Singapore issues' is used to refer to the four government policy areas identified here in the main text plus the labour and environmental standards. After the Seattle Ministerial Conference, the term Singapore issues was rarely used in official circles to refer to anything other than the four areas of government policy identified in the main text.

${ }^{5}$ The European Union (EU) is known for legal reasons as the European Communities in WTO matters. The 27 member states of the EU are WTO members in their own right. The European Commission speaks for all EU member states at almost all WTO meetings.
} 
Table 1: Summary of leading proposals for additional multilateral disciplines in investment, competition, transparency in government procurement, and trade facilitation

\begin{tabular}{lll}
\hline Topic & $\begin{array}{l}\text { Leading proponent } \\
\text { of additional } \\
\text { disciplines }\end{array}$ & Additional disciplines sought \\
\hline $\begin{array}{l}\text { Trade and } \\
\text { investment }\end{array}$ & $\begin{array}{l}\text { European } \\
\text { Communities }\end{array}$ & $\begin{array}{l}\text { 1. GATS approach (positive list) proposed for inclusion of sectors } \\
\text { for which the following proposed disciplines }\end{array}$ \\
& $\begin{array}{l}\text { 2. Measures to improve transparency of national investment } \\
\text { regimes comparable to those in the GATS agreement }\end{array}$ \\
& $\begin{array}{l}\text { 3. Extend applicable non-discrimination principles in the GATS } \\
\text { agreement to other forms of direct investment }\end{array}$ \\
& $\begin{array}{l}\text { 4. Extend applicable pre-establishment disciplines in the GATS } \\
\text { agreement to other forms of direct investment }\end{array}$ \\
$\begin{array}{l}\text { 5. Inclusion of a balance-of-payments safeguard for developing } \\
\text { countries }\end{array}$ \\
$\begin{array}{l}\text { 6. Inclusion of 'development provisions' to provide cross-cutting } \\
\text { 'flexibilities' across all horizontal disciplines outlined above }\end{array}$ \\
$\begin{array}{l}\text { 7. Definition of included investment includes all direct } \\
\text { investments where the investor owns } 10 \text { per cent or more of } \\
\text { the voting stock } \\
\text { 8. All disciplines in this area subject to WTO dispute settlement }\end{array}$
\end{tabular}

United States

1. Inclusion of portfolio investment flows (taken to include a broad range of financial instruments) as well as direct investments in any multilateral disciplines

2. WTO members should be as open to portfolio investments as they are to direct investments

\begin{tabular}{ll}
\hline $\begin{array}{c}\text { Trade and } \\
\text { competition }\end{array}$ & European \\
Communities
\end{tabular}

1. A commitment to adhere to a set of core principles (transparency, non-discrimination, procedural fairness) in the application of competition law

2. A commitment to enact and enforce a law against hard-core cartels

3. The developments of modalities for voluntary cooperation on competition law and policy matters between WTO members

4. A commitment to support the introduction and strengthening of competition laws and related institutions in developing countries

$\begin{array}{lc}\begin{array}{c}\text { Transparency in } \\ \text { government } \\ \text { procurement }\end{array} & \text { European } \\ & \text { Communities }\end{array}$

1. Measures on the following matters should be part of a multilateral agreement: choice of procurement method; providing information on national legislation and procedures; publication of procurement opportunities and procedural requirements; information supplied; time-limits for procurement processes; decisions made on supplier qualification and contract award; domestic review procedures; language used in official documentation; and use of information technology

2. Measures to promote transparency including ensuring information on procurement practices, rules and opportunities are made widely available in an easily usable form to all interested parties. Favoured a 'principles-oriented' approach rather than prescriptive rules

3. Inclusion of a provision on technical assistance that mirrors the language of Article 67 of the TRIPS agreement 
Table 1: (Continued)

\begin{tabular}{|c|c|c|}
\hline Topic & $\begin{array}{l}\text { Leading proponent } \\
\text { of additional } \\
\text { disciplines }\end{array}$ & Additional disciplines sought \\
\hline & Japan & $\begin{array}{l}\text { 1. Recognizing the difficulties that developing countries have with } \\
\text { the existing transparency provisions of the plurilateral } \\
\text { Agreement on Government Procurement, Japan argued for a } \\
\text { flexible approach based on core principles. The approach } \\
\text { would be legally binding and enforceable } \\
\text { 2. The following measures would be covered by the agreement: } \\
\text { non-discrimination in transparency; definition and scope; core } \\
\text { transparency principles; domestic review procedures; } \\
\text { consultations and dispute settlement; technical assistance; } \\
\text { and special and differential treatment for developing countries }\end{array}$ \\
\hline & Korea & $\begin{array}{l}\text { 1. Measures on the following matters should be part of a } \\
\text { multilateral agreement: scope and definition (of covered } \\
\text { government procurement; measures to improve transparency } \\
\text { of procurement-related measures, award decisions, and } \\
\text { domestic review processes; exceptions; dispute settlement; } \\
\text { special and differential treatment; and technical assistance } \\
\text { 2. All measures would be legally binding and subject to WTO } \\
\text { dispute settlement }\end{array}$ \\
\hline & United States & $\begin{array}{l}\text { 1. Measures to establish 'core transparency elements'. It was } \\
\text { argued that these need not be specified 'at this juncture' } \\
\text { 2. Explicit conditions would be specified for when single } \\
\text { tendering by procuring bodies would be allowed and for } \\
\text { transparency associated with such single tendering } \\
\text { 3. Commitments on independent review mechanisms that ensure } \\
\text { impartiality, that allow for rapid decisions including the } \\
\text { possibility of suspending the procurement process, and that } \\
\text { grant adequate remedies } \\
\text { 4. Noted that disciplines on preference programmes were } \\
\text { explicitly precluded }\end{array}$ \\
\hline $\begin{array}{l}\text { Trade } \\
\text { facilitation }\end{array}$ & $\begin{array}{l}\text { European } \\
\text { Communities }\end{array}$ & $\begin{array}{l}\text { 1. With respect to GATT Article V (Freedom of Transit), in } \\
\text { addition to measures to simplify, limit, and standardize } \\
\text { customs procedures and documentation requirements, the EC } \\
\text { proposed a broadening of National Treatment provisions on } \\
\text { modes of transport and provisions on technical assistance and } \\
\text { special and differential treatment for LDCs } \\
\text { 2. With respect to GATT Article VIII (Fees and Formalities), the } \\
\text { EC suggested requiring the reduction in the incidence and } \\
\text { complexity of import and export formalities. Non-discrimination } \\
\text { across modes of transportation was sought, too. Provision for } \\
\text { special and differential treatment would be made } \\
\text { 3. With respect to Article X (Publication and Administration of } \\
\text { Trade Regulations), the EC emphasized a commitment to } \\
\text { transparency through the publication of all relevant } \\
\text { information, the establishment of enquiry points for traders, } \\
\text { and procedures to make fast and advance rulings for traders. } \\
\text { Again, provisions on technical assistance and special and } \\
\text { differential treatment were sought }\end{array}$ \\
\hline
\end{tabular}


Table 1: (Continued)

\begin{tabular}{|c|c|c|}
\hline Topic & $\begin{array}{l}\text { Leading proponent } \\
\text { of additional } \\
\text { disciplines }\end{array}$ & Additional disciplines sought \\
\hline & Canada & $\begin{array}{l}\text { 1. With respect to GATT Article V (Freedom of Transit), in } \\
\text { addition to measures to simplify, limit, and standardize customs } \\
\text { procedures and documentation requirements, Canada } \\
\text { proposed a broadening of National Treatment provisions, but } \\
\text { only in so far as relates to internal taxation and the regulation } \\
\text { of goods. Envisaged support for technical assistance } \\
\text { 2. With respect to GATT Article VIII (Fees and Formalities), } \\
\text { Canada recommended the standardization and compatibility of } \\
\text { data sets, with the eventual goal of furthering coordination of } \\
\text { procedures and formalities between customs agencies } \\
\text { 3. With respect to GATT Article X (Publication and Administration } \\
\text { of Trade Regulations), Canada's goal was to promote the } \\
\text { WTO principles of transparency, due process, integrity, } \\
\text { efficiency, simplification, and consultation. Rights to comment } \\
\text { on proposed trade rules on this matter, as well as rights to } \\
\text { appeal against administrative decisions, were proposed }\end{array}$ \\
\hline & Korea & $\begin{array}{l}\text { 1. With respect to GATT Article V (Freedom of Transit), in } \\
\text { addition to measures to simplify, limit, and standardize } \\
\text { customs procedures and documentation requirements, Korea } \\
\text { stressed cooperation and sharing of information among } \\
\text { customs authorities, harmonization of policies, standardization } \\
\text { and uniformity of datasets, and transparency. Provision for } \\
\text { technical assistance was envisaged } \\
\text { 2. With respect to GATT Article VIII (Fees and Formalities), } \\
\text { Korea specifically argued for the use of accepted WTO/GATT } \\
\text { principles in interpreting matters relating to this Article }\end{array}$ \\
\hline
\end{tabular}

on these four matters, too, but often proposed different multilateral disciplines to those put forward by the EC. The United States was particularly interested in negotiations on further multilateral disciplines on national investment and government procurement policies. In this respect, it is worth noting that for three of the four Singapore issues there exist already binding multilateral disciplines; the latter provided some reference points for the discussions among the WTO membership. For competition law and policy, there are some provisions in the General Agreement on Trade in Services (GATS) and in the Agreement on Trade-related Intellectual Property Rights (TRIPS) that refer to anti-competitive practices. Moreover, some experts ${ }^{6}$ argued that the GATT's national treatment disciplines already applied to competition law and its enforcement, thereby linking proposals for further disciplines to one significant principle in the WTO legal architecture. In sum, the extent to which the four Singapore issues were 'new' to the multilateral trading system was debatable. Furthermore, as the observation above about national treatment implies, the notion that these proposed disciplines took the WTO 'behind the border' for the first time is extremely dubious.

The working-group processes proved to be inconclusive; no consensus emerged out of any of them. Proponents of each Singapore Issue described in broad terms the multilateral disciplines they were calling for. Opponents tended to regard the submission of legal text as

\footnotetext{
${ }^{6}$ In particular Professor James Mathis.
} 
premature. Major decisions on Singapore-issues-related matters were typically taken by these groups' ministers, who rarely, if at all, attended the working groups. The inconclusive outcome allowed WTO members to draw different, even potentially contradictory, conclusions about the level of support for launching negotiations on these matters, and to take those disparate conclusions with them to the subsequent Cancún Ministerial Conference. During 2003, groups of developing-country trade ministers came together and, using different formulations, called for the clarification process for the Singapore issues to be continued after the Cancún Ministerial Conference, thereby rejecting the option of launching multilateral negotiations on these matters. ${ }^{7}$ These declarations also called for further work to be completed on the trade matters of particular interest to developing countries.

These deliberations on the Singapore issues did not proceed without reference to other developments in the Doha Round (see Hoekman and Newfarmer, 2003). None of the associated deadlines were met and frustration at the lack of progress in one area often led to a slower pace, if not complete standstill, in others. ${ }^{8}$ Moreover, several matters further exacerbated tensions between WTO members. First, developing countries criticized the two draft Ministerial Declarations circulated before and during the Cancún Ministerial Conference as not sufficiently reflecting their interests. ${ }^{9}$ This criticism is probably stronger in the case of the second draft Ministerial Declaration. The first draft Ministerial Declaration (issued on 23 August 2003) contains almost identical and opposed text in square brackets (indicating the absence of agreement); one part calling for negotiations on each Singapore issue to begin, and the other for the process of clarification to continue. It is difficult to see how this balanced, if inconclusive, formulation is biased. But the second draft Ministerial Declaration (issued on 13 September 2003), however, explicitly called for negotiations to begin on trade facilitation and on transparency in government procurement, to launch negotiations on trade and investment matters no later than the date upon which WTO members agree to finalize the modalities for negotiating agricultural and non-agricultural trade reform, and a proposal to continue the clarification process on the interaction between trade and competition policy. The second draft Ministerial Declaration is clearly at odds with the statements (noted above) of a number of groups of developing countries on the Singapore issues. One could argue that the proposed Ministerial Declaration was an attempt to find a compromise between WTO members - if an ill-fated one. There were potential compromises closer to the stated positions of developing countries and the fact that they were not chosen may well have been a source of grievance.

The next source of friction concerned agricultural trade reform and the rejection by a group of large developing countries (WTO members known collectively as the G-20) of a compromise set of modalities proposed jointly by the EC and the USA. The WTO membership had called on the EC and the USA to narrow their differences on agriculture before the Cancún Ministerial Conference. The latter two parties sought to do this, but on terms that the WTO membership rejected. The subsidization of cotton production was the third item to sour relations between WTO members. Four very poor African countries

\footnotetext{
${ }^{7}$ See, for example, the Declaration of Second LDC Trade Ministers, Dhaka, Bangladesh, 31 May-2 June 2003 (which 49 least-developed countries (LDCs) signed), the African Trade Ministers Meeting, Grand Baie, Mauritius, 19-20 June 2003 (which 53 nations attended), and a subsequent submission to the WTO by 12 developing countries on 4 July 2003.

${ }^{8}$ In this regard it is noteworthy that Ismail (2005) argued that insufficient progress towards a balanced outcome had been made before the Cancún Ministerial Conference. Ambassador Ismail represents South Africa at the WTO, a post he has held for much of the Doha Round.

${ }^{9}$ The comments of one senior Bangladeshi trade diplomat on this matter can be found in Ahmed (2003).
} 
complained that these subsidies were depressing the world price of cotton and adversely affecting the livelihood of many of their citizens, and demanded action on the part of the principal subsidiser of this product, namely the United States. This demand was not expected and came as a surprise to most WTO members and observers. The reaction from the US delegation to such requests was to encourage diversification of the four African economies concerned, rather than offering to cut or even contemplate cutting the subsidies in question. This response met with indignation from many developing-country diplomats. In the light of these considerations (missed deadlines indicating few or no satisfactory trade-offs made across negotiating items; rejection of the US-EC agricultural compromise; the rejection of the second draft Ministerial Declaration; and the mishandling of the cotton subsidies matter) it is not terribly surprising that the Cancún Ministerial Conference ended without agreement among the WTO members.

The prominence of the Singapore issues in the breakdown is precisely because, even though it was the first topic to be discussed in the Green Room, ${ }^{10}$ WTO members could not come to an agreement over which Singapore issues to launch negotiations on, after which the Chairman decided to conclude the Ministerial Conference without agreement. ${ }^{11}$ Towards the end of the deliberations, the European Commissioner for Trade offered to drop two of the four Singapore issues, whereas the ACP group of developing countries insisted that negotiations could not begin on any of them. Korea and Japan were said to have demanded that negotiations start on all four issues, even after the EC's concession. Rather than move on to the second and third items that the Chairman had identified for discussion in the Green Room (namely, agricultural trade and trade in industrial products) and possibly returning to the Singapore issues should progress be made in other areas, Luis Debrez, the then Minister of Foreign Affairs of Mexico, chose to conclude the Ministerial Conference. This decision either reveals much about Mr Debrez's judgement or much about the perceived willingness of the WTO membership at that time to make trade-offs across diverse negotiating items.

The fate of the Singapore issues in the Doha Round was formally sealed in the WTO General Council at the beginning of August 2004. The 'July 2004 package' was assembled to put the Doha Round negotiations back 'on track', if not on schedule. WTO members decided to stop for the duration of the Doha Round all work on the interaction between trade and investment policies, the interaction between trade and competition policy, and transparency in government procurement. It was agreed to launch negotiations on further trade-facilitation measures. This set of decisions was necessary as there was no clear guidance in previous Ministerial Declarations on how to treat the Singapore issues after the Cancún Ministerial Conference.

Having charted the manner in which the Singapore issues entered WTO deliberations and, for the time being, how only one Issue remains part of the WTO's work programme, I now turn to describing and assessing five hypotheses that individually or in combination may account for the fate of the Singapore issues in the early years of the Doha Round.

\footnotetext{
${ }^{10}$ The Green Room is WTO-speak for the place where negotiations occur between a subset of WTO members typically invited by the WTO Director General. Formally, agreements made in the Green Room are not sufficient to become WTO agreements. The entire WTO membership must agree before the latter can occur.

${ }^{11}$ Interestingly, observers as diverse as Pascal Lamy, then Commissioner of Trade for the EC, and Martin Khor (of the Third World Network) blamed the collapse of the Cancún Ministerial Conference on the WTO's decision-making procedures and not on the Singapore issues (see Lamy, 2003; Khor, 2003). It may be revealing that in hindsight it has been very difficult to find articles about this Ministerial Conference that argue that the Singapore issues were the sole cause, or even the most important cause, of the collapse. Sandrey (2006) is an exception.
} 


\section{Five hypotheses concerning the fate of the Singapore issues}

The goal here is to understand better why negotiations on the four Singapore issues were not launched in the early years of the Doha Round. Thinking through the reasons for the demise of the Singapore issues is not just of interest for understanding the contemporary trade policy record, it may have implications should a nation or group of nations seek to raise these matters at the WTO in the future. If the reasons for the rejection of the Singapore issues were Doha-Round-specific or otherwise context-specific, then those reasons may not apply in the future. If, on the other hand, features fundamental to the world trading system are incompatible with core elements of the Singapore issues, then the Doha Round experience could cast a long shadow over the future scope of the WTO's rules.

The five hypotheses concerning the fate of the Singapore issues can be succinctly described as (i) wrong tactics, (ii) wrong proponent, (iii) wrong timing, (iv) wrong proposals, and (v) wrong institution. In the remainder of this section I describe and evaluate each hypothesis in turn.

\section{(i) Wrong tactics}

The thrust of this hypothesis is that, while the Singapore issues may have been consistent with WTO principles and practice, and the proposals advanced by the proponents provided a sound foundation upon which to negotiate multilateral disciplines, the tactics of the EC, the principal proponent, left much to be desired. The first argument in support of this hypothesis is that it was a mistake for the EC to insist that the four Singapore issues be considered together for inclusion in the Single Undertaking. But it is not apparent why the four sets of proposals for additional multilateral rules formed a coherent package and, therefore, why they needed to be subject to a single decision by WTO members. ${ }^{12}$ Indeed, the EC often made the case for each Singapore Issue without reference to the other three Singapore issues under consideration by the WTO membership. ${ }^{13}$ Worse, the absence of any substantive and well-articulated rationale for combining all four Singapore issues may have given rise to the impression that the EC's approach is this respect was entirely tactical. Moreover, the EC's wish to have the package of Singapore issues considered together may have strengthened the perception that there was direct trade-off with other elements of the Doha Round negotiating agenda. If the EC sought to create that impression, then arguably over time it proved more counterproductive as the perceived lack of progress on other matters of interest to developing countries, before and during the Cancún Ministerial Conference, may have made it easier for the ACP nations to reject negotiations on all four Singapore issues.

\footnotetext{
${ }^{12}$ It does not follow that supporting a case for the inclusion of each Singapore issue in the Single Understanding must imply supporting the case for bundling all four issues together into a single decision concerning inclusion.

${ }^{13}$ Quite a distinct criticism concerns whether the EC sufficiently demonstrated some of the linkages across some of the Singapore issues or exploited those linkages in making its case to the WTO membership. For example, so many contemporary foreign direct investments are in fact cross-border mergers and acquisitions. A coherent package of measures concerning the overseas expansion of firms would need to take into account considerations of investment policy (pre- and post-establishment) and competition law and its enforcement (in particular, the law on mergers and acquisitions).
} 
The timing of the subsequent decision by the EC to consider differentiated outcomes for the Singapore issues and the eventual decision to propose dropping two of these issues from the Doha Round's Single Undertaking was considered by certain observers as too little, too late to save the few Singapore issues that some believe did have the requisite support among the WTO membership to launch multilateral negotiations (White \& Case, 2003). If the EC had hoped that progress in other areas of the Doha Round would make the other WTO members amenable to launching negotiations on all four of the Singapore issues, then the sequence of missed deadlines in the run-up to the Cancún Ministerial Conference might have suggested that the prospects of agreeing modalities had diminished, in which case an earlier concession (whereby negotiations were launched for some issues and the others remained in 'study mode') might have yielded a better outcome than that which came to pass. ${ }^{14}$ White \& Case (2003), for example, in their report on the Cancún Ministerial Conference, contend that as early as the Seattle Ministerial Conference there was enough support among the WTO membership to launch negotiations on multilateral disciplines on trade facilitation and transparency in government procurement. (The latter point need not be true to sustain the original point that the EC's concessions were too little, too late.)

Another tactical consideration concerned the arguments the EC tried to use to persuade its trading partners of the merits of the Singapore issues. Up until 1999, by and large, the EC argued that there were market-access-related benefits to multilateral disciplines on each of the four Singapore issues. From 1999 the EC changed tack and officials argued that the four Singapore issues were of generic interest to members of the WTO, including to developing countries, and that no WTO member should have to 'pay for' the inclusion of these beneficial global rules. It was sometimes argued that the four Singapore issues would contribute to 'harnessing globalization' and to a more equitable sharing of its benefits, and therefore negotiations on these matters should be supported by all because of their systemic value (Lamy, 2004). This amounts to a departure from the traditional reciprocity-based approach to trade negotiations and (in the minds of critics) conveniently absolved the demandeurs of these rules of the need to 'pay' for their negotiating requests.

A further challenge to the argument that the Singapore issues were clearly of systemic interest is that, if they really are of interest to developing countries, then why did so few poor countries concur with this assessment during the pre-Cancún deliberation phase? Other than a few positive statements from Costa Rica concerning multilateral rules on the interaction between trade and competition policy, before the Cancún Ministerial Conference it is difficult to find much developing-country support for even the principle of additional multilateral rules in these four areas of government policy. Of course, it is possible that some developing

\footnotetext{
${ }^{14}$ An implication of the missed deadlines before the Cancún Ministerial Conference is that, in effect, all of the bargaining would have to take place at the Ministerial Conference. On this expectation the EC may have been loath to make a proposal for differentiated treatment of the Singapore issues before this Ministerial Conference began, because of fears that the associated concession would have been 'pocketed', that is, not reciprocated by other WTO members. This observation indicates some of the difficulties in devising negotiating strategies when a series of sequential negotiations on various components of a package are inconclusive and the associated deadlines are missed, which in turn hardens the positions of some or all of the negotiating parties. Under these circumstances, the subsequent Ministerial Conference is not where the loose ends of the negotiations are tied up (as might have been envisaged), but the venue where the negotiations on all related matters effectively begin in earnest. This last observation raises systemic questions about how best to organize a negotiation on a package with many different elements, as well as questions about what the optimal negotiating strategy is for a major player in those negotiations.
} 
countries would not have minded the negotiation of these rules but felt that, in a reciprocitybased negotiation, they would have had to offer something in return for making demands on the Singapore issues.

Questions might also be raised about the choices that the proponents either agreed to or acquiesced to in the organization of the discussions of the Singapore issues from 1996 onwards. As noted earlier, three of the Singapore issues were discussed in especially created working groups. While, on the face of it, it is difficult to object to a process that allows deliberation and discussion among WTO members, this does not imply that the workinggroup process was not without its faults. One might wonder how much serious deliberation of members' positions really took place in an international organization where negotiation is one of the primary functions and where each member knew that the deliberation process on the Singapore issues was to be followed by a decision about whether to launch negotiations. This raises the question of whether the discussions in the working groups were essentially quasi-negotiations, hamstrung by the façade of deliberation. Another generic problem with the working-group process was that it tended to engage middle-ranking officials whose relationship to the real decision-makers (trade ministers and their most senior officials) was not always apparent.

\section{(ii) Wrong proponent}

In a reciprocity-based process of trade negotiation the reception of a proposal is rarely divorced from the identity of the proposer. The second hypothesis is that the Singapore issues met their demise because the European Commission, its principal proponent, and some other proponents (notably Japan and Korea) were not seen as credible demandeurs. Some contended that the proposals for launching negotiations on the Singapore issues were no more than a ruse to delay awkward negotiations on trade-policy matters on which the EC and others would find it hard to make concessions, such as agriculture (Kol and Winters, 2004). In the writings of other opponents to the Singapore issues there was the firmly held conviction that the EC would not be willing to offer much in terms of market-access concessions or domestic support for reform in agriculture in return for concluding agreements on the Singapore issues. This perception — and, let us be frank, it is only a conjecture — may have inadvertently been reinforced by the European Commission's argument that the Singapore issues were of systemic interest and that the proponents should not have to 'pay for' them with concessions. ${ }^{15}$ Moreover, if an observer took the view that it is EU budgetary constraints that principally determine the pace and extent of agricultural trade reform in Europe, then it may not be unreasonable to conclude that the likely pay-off to agricultural exporters from accepting multilateral disciplines on the Singapore issues would be limited.

\section{(iii) Wrong timing}

The third hypothesis essentially states that the fate of the Singapore issues in the Doha Round was a product of timing and circumstance, in particular the perceived legacy of the Uruguay Round. Just after the WTO was established, the EC (among others) sought to persuade its

\footnotetext{
${ }^{15}$ The EC was clear, however, in stating that it would offer technical assistance to developing countries, should additional multilateral disciplines be negotiated.
} 
trading partners of the value of new multilateral trade rules on certain matters (not just the four government policies considered in this paper, but also those related to certain labour standards and environmental policies). In retrospect, the timing of these proposals could not have been worse. The widespread optimism in the mid-1990s about the prospects of the world trading system, with its new international organization and dispute-settlement mechanism, among Western trade negotiators, international trade lawyers, public international lawyers, and, for that matter, quite a few international trade economists, did not resonate with other (in particular developing-country) members of the international-trade-policy community.

This optimism was short-lived as the view took hold in some quarters that the Uruguay Round was not as balanced or as beneficial as many had originally thought. ${ }^{16}$ Some contended that the cost of implementing the Uruguay Round obligations for certain developing countries might have substantially, if not entirely, consumed the benefits of the Round's trade reforms (see Finger (2007), in his contribution to this issue). Others argued that promises of technical assistance and aid, allegedly made at the end of the Uruguay Round by industrialized countries, were reneged upon. Another argument put forward was that the Uruguay Round's actual impact was such that developing countries bore high implementation costs (associated with establishing and upgrading national regimes with regard to intellectual property rights, product standards and testing, and the like) and that the greatest benefits for developing countries were put off for 10 years (with the phase-out of the Multi-fibre Arrangement (MFA)) or were contingent on completing negotiations of interest to poor countries (such as agricultural reform) at some point in the future. Finally, some argued that the negotiation of the TRIPS agreement in the Uruguay Round demonstrated that an agreed-upon negotiating mandate that was initially narrow could be expanded substantially over time, ultimately to the detriment of developing countries - or so this argument goes (Woolcock, 2003). Taken together, these points amounted to a wide-ranging critique of the set of Uruguay Round multilateral trade agreements, their effects, and the process by which they were negotiated. The veracity of each and every element of the above critique of the Uruguay Round can be contested. However, for the purposes of this paper, what is important is not what is true but what was persuasive. Under this hypothesis, then, the die of the Singapore issues was almost certainly cast soon after the completion of the Uruguay Round.

One potential variant on hypothesis three is to fuse it with hypothesis two. Bearing in mind that the EC and the USA were largely responsible for jointly determining the outcome of the Uruguay Round, and given that both wanted at least two of the Singapore issues to be part of the Single Undertaking in the Doha Round, having blamed these Western trading powers for their paltry benefits from the Uruguay Round and in the absence of any serious movement on the so-called implementation matters, some developing countries may well have been determined to deliver a bloody nose to the leading proponents of the Singapore issues. More generally, the fate of the Singapore issues in the Doha Round could be seen as part of the rest of the WTO membership reminding the two long-standing poles of the multilateral trading system that their domination is over. On this view the Singapore issues are victims of history, geopolitical changes, and institutional circumstance.

\footnotetext{
${ }^{16}$ In my view this widespread change in view is worthy of its own objective intellectual history. It would be useful to learn what evidence persuaded trade analysts to change their view and then evaluate the soundness of that evidence and the policy implications drawn from that evidence.
} 


\section{(iv) Wrong proposals}

In principle, the very proposals for additional multilateral obligations on the four Singapore issues could alone provide grounds for opposition to launching negotiations. Here, the concern is not that these matters should not be addressed in the WTO at all (that is the subject of the next hypothesis), rather that the proposals themselves are deficient in some way and therefore should not provide the basis of a multilateral negotiation. In the run-up to the Cancún Ministerial Conference, some analysts, trade negotiators, and even ministers criticized the content of the proponents' proposals. ${ }^{17}$ (Indeed, Evenett and Hoekman (2005), the first draft of which was written before the Cancún Ministerial Conference, contained criticisms of the EC's proposals to limit negotiations on additional multilateral disciplines on government procurement to transparency-related matters.) A balanced assessment of the proponents' proposals would require a detailed account of those proposals, the extant and relevant economic and development literature, and other pertinent considerations (see SECO and Evenett, 2003). Here, however, I comment on the principal generic criticisms of the proponents' proposals. Readers should not infer that, because a criticism is described below, that it is particularly well thought-through or, indeed, related to anything that was proposed by the demandeurs of the Singapore issues. A claim does not have to be true to be persuasive in policy circles.

The development mandate was also used to question the relevance of some proposals to developing countries. In some critiques the implicit assumption seemed to be that every proposal must be directly relevant to the well-being of developing countries. But why cannot a package of proposals contain some elements of interest to some WTO members and other elements of interest to another group of WTO members (assuming that any adverse knock-on effects of both elements do not eliminate the net benefit of the package's expected impact)? In such situations the overall assessment should be made on the expected impact of the entire package, rather than on individual elements of the package.

A generic criticism of the Singapore issues was that they would encroach on the so-called policy space of developing countries. It was argued that additional multilateral disciplines in these four areas of government policy would prevent developing countries from taking measures that would promote their development. Some went further and argued that this encroachment on national policy autonomy would prevent poorer countries from pursuing the same policies that industrialized countries had used in the past. This latter appeal to parity relies on assumptions that industrial countries actually used the very same policy space that the proponents of the Singapore issues apparently seek to preclude; that if such policy space was used, it was effective; that no alternative allowable policy instruments of equal effectiveness now exist; and that more effective policies to attain the stated development goals have not been subsequently identified and successfully implemented. On my reading of the literature, there has been little attempt to demonstrate that the latter assumptions hold true.

In Evenett (2003a) I examined whether the proposed binding disciplines on the enactment and enforcement of so-called hard-core cartels and non-discrimination in the enforcement of competition law would preclude the adoption by developing countries of government measures that had made a non-trivial contribution to successful national development policies. I reviewed the extensive literature on the use of 'industrial policy' by the governments of

\footnotetext{
${ }^{17}$ I should add that before and since the Cancún Ministerial Conference there were few assessments of the proponents' proposals that made specific reference to the actual proposals advanced for multilateral disciplines, which is unsatisfactory, if not outright bizarre.
} 
the fast-growing East-Asian economies (a literature incidentally written almost exclusively by critics of free markets) and found, to my surprise, that these governments rarely resorted to cartelization among domestic firms, forced mergers, or discriminatory enforcement of competition law. ${ }^{18}$ To the extent that governments intervened to influence the degree of rivalry among domestic firms, the evidence pointed to measures being adopted to promote competition. This review cast doubt on the contention that the proposed multilateral framework on competition policy would have slowed down or frustrated the so-called East-Asian Miracle, and that this framework would prevent other developing countries from adopting the policy mix that contributed to East Asia's spectacular growth.

Moreover, it was acknowledged by proponents of a multilateral framework on competition policy that WTO members could seek exceptions from any binding disciplines in the event of a substantial clash between the proposed obligations and national development policy. So, even if there was an encroachment on useful policy space, a solution that did not undermine development prospects was envisaged. In the light of these arguments the notion that proponents were trying to kick away the development ladder before poor countries could scramble up it does not bear scrutiny, certainly not as far as the proposals for a multilateral framework on competition policy are concerned. Furthermore, when one considers how rarely, if ever, one hears of development success stories based on degrading a nation's trade facilitation infrastructure, on greater delays and costs at ports and airports, and on non-transparent public-procurement policies, one wonders just how ridiculous is the claim that the need to preserve the policy space of developing countries provides compelling grounds to reject the Singapore issues.

A different criticism of the proposals advanced was that they were unlikely to deliver substantial gains to WTO members (in particular developing countries) and, therefore, were not a priority. In an ideal world this criticism would have been backed up by solid empirics demonstrating that the implementation of the proposed multilateral disciplines associated with Singapore issues would be likely to generate substantially fewer benefits than the implementation of liberalizing commitments in agricultural trade, non-agricultural trade, or services. ${ }^{19}$ I could find no study that contains any such comparison, let alone a systematic comparison. Even if I could, given the repeated downward revisions over time in the gains from the trade reforms in agriculture, industrial products, and services expected to flow from the completion of the Doha Round, ${ }^{20}$ any ranking of national negotiating priorities may well have been reversed over time. Moreover, even if the pre-Cancún proposals for the Singapore issues were expected to yield less than successfully concluding agreements on other elements in the Doha Round negotiating agenda, it does not automatically follow that

\footnotetext{
${ }^{18}$ With the exception of Japan, most of the countries considered did not adopt competition laws until well into, or after, their fast growth phases, so the finding that they did not apply their competition laws in a discriminatory manner is not terribly surprising. Even so, it does serve as reminder that this form of discrimination could not have been part of the policy mix that contributed to the fast growth phase.

${ }^{19}$ If one really wanted to be difficult here, one could argue that this empirical comparison is not enough. To demonstrate convincingly that under no plausible circumstances are the Singapore issues a priority for developing countries, one would have to show that none of the set of potential multilateral disciplines delivers gains to developing countries that are of the same order of magnitude as the expected benefits from trade reform in agricultural products, industrial products, or services. Indeed, given that the negotiating agenda at the WTO is not confined to the last three matters, one might compare the potential benefits from a Singapore issue favourably with the benefits likely to follow from any new multilateral rules on antidumping, especially if it is correct to expect very little in terms of new rules to restrict this form of contingent protection.

${ }^{20}$ Readers may recall that the World Bank cut its estimates of the net benefits of completing the Doha Round negotiation by 80 per cent over the 4-year period 2001-5.
} 
negotiations of the former should be rejected. Another perfectly legitimate response would be to propose even more ambitious multilateral rules for the Singapore issues that delivered greater expected gains. For some reason this logical possibility eluded the critics.

Further thought about the merits of criticisms concerning the priority that should be given to the Singapore issues raises other considerations. Surely whether a negotiating matter is a priority ought to depend on the feasibility of successfully concluding the negotiations, as well as their likely economic impact. Many of the critics of the Singapore issues seem to have downplayed their likely economic impact and, given subsequent events, overestimated the likely effects of, and quite probably the likelihood of successfully negotiating, the liberalization of goods trade, agriculture, and services. A proper analysis of negotiating priorities ought to be transparent about the assumptions made in this regard and their rationale.

Another factor that probably coloured assessments of negotiating priorities is that most international trade economists are better informed about market-access-related matters than about the relationships between trade policies and the various government policies often referred to as 'inside the border'. These analysts may have discounted what they do not know or do not know so well, skewing their assessments against the Singapore issues. One reaction to this argument is that the burden of proof lies with the proponents of additional multilateral disciplines. This may well be a good tactical argument on the part of negotiators and government officials, but it will not stand for purportedly independent scholars and analysts. It could just as well be argued that those who produce scholarly and other assessments, whose credibility derives from their perceived expertise and independence, have a duty to inform themselves as much as possible. This, in turn, raised questions about the adequacy of the empirical evidence on the Singapore issues to which I now turn.

In SECO and Evenett (2003), for each Singapore issue my colleagues and I identified the empirical evidence cited by proponents of the Singapore issues and did our best to summarize the relevant empirical economic literature. The degree to which proponents employed empirical evidence varied, and some deficiencies were identified in this respect (especially concerning some of the evidence used by the EC to advance its proposals for additional multilateral rules on investment). The question arises as to whether there was an adequate or minimum necessary empirical base upon which thoughtful advice to policy-makers could be developed. In the case of the Singapore issues, there is room for some discomfort here, and policy-making may well have got too far ahead of the body of available knowledge. In considering the severity of this criticism, it is worth bearing in mind that survey after survey shows (see, for example, Deardorff and Stern, 1998) that the empirical evidence on the effects of non-tariff barriers and, most importantly for policy-making purposes, on the effects of international trade disciplines on the impact of non-tariff barriers, is very thin on the ground. The latter argument should not be seen as an excuse; more evidence on the impact of the effects of the Singapore-issue-related trade provisions is needed, just as it is needed in non-tariff barriers, service-sector regulatory barriers, etc. Rather, the point is that the Singapore issues are not particularly unusual in this respect and should not be singled out for extraordinary criticism.

\section{(v) Wrong institution}

Among academics, perhaps the most interesting criticisms of the Singapore issues turned on the contention that, even if there is a case for international collective action on a 
particular policy instrument or instruments, such an initiative should not be located within the WTO - that is, within a multilateral trading system with binding rules and dispute settlement. Essentially, these criticisms amounted to arguing that the proposed disciplines fell outside the boundaries of the WTO. I argue below that the force of this criticism is blunted once one takes on board the inconvenient fact that there is no widely accepted formulation of what should constitute the boundaries of the WTO. In particular, I argue that criteria based on economic considerations alone do not support a narrow set of boundaries for the WTO.

First, however, let me set to one side some of the less thoughtful boundary-based criticisms of the Singapore issues. Arguments that the policy instruments associated with the Singapore issues were not trade-related are hard to square with, for example, the very purpose of trade-facilitation measures. Arguments that the WTO should not go 'beyond the border' are vitiated by the widespread acceptance of various multilateral disciplines on national treatment, which are designed specifically to apply to policy instruments inside the border. Arguments that the WTO should confine itself to cross-border trade in goods and services ignore the fact that much international commerce takes place in or between entities that do not involve products or persons crossing borders. Given that goods and services transactions worth trillions of dollars are associated with the latter, a focus on cross-border trade could call into question the WTO's relevance in today's highly integrated world economy to a wide range of its members. I mention these objections to the Singapore issues not because they should be taken that seriously, but rather because they explicitly or implicitly underlie several of the critiques levelled at the proposals for additional multilateral rules.

Ideally, a coherent set of principles would guide the determination of what disciplines should be introduced into the WTO. Analysts have attempted to provide these principles (see Maskus, 2002; Lloyd, 2005; Wolfe, 2007; and, in so far as it relates to plurilateral agreements, Lawrence, 2006). ${ }^{21}$ I summarize their main arguments and their relevance for understanding the opposition to the inclusion of the Singapore issues in the Single Undertaking of the Doha Round.

Maskus (2002) accurately and succinctly summarizes the mainstream position of policyaware international trade economists, at least as I see it. He argues as follows:

Specifically, economists recognize four general principles when considering the need for a negotiated set of multilateral disciplines to restrain government action or mandate certain standards. First, are existing regulations . . . 'trade related' in the sense of significantly distorting trade flows? Second, do those regulations impose externalities on other countries that limit the attainment of global optimality and can multilateral rules internalize those costs? Third, if left to unilateral action, do countries choose policies that result in globally inadequate regulations, requiring policy coordination? Fourth, is it possible to compute and assign damages from failing to comply with international trade rules, thereby making dispute settlement a feasible task. (p. 136)

On the basis of his criteria and assessment of the evidence, Maskus concludes that, given the TRIPS agreement, there is a strong case for including competition rules in the WTO. In contrast, he finds that there is a weak case for including environmental policies, and an even weaker case for including rules on labour standards in the WTO.

\footnotetext{
${ }^{21}$ My own rather feeble effort in this regard can be found in Evenett (2003b).
} 
With respect to Maskus's criteria, let me begin by noting that only his first two criteria relate to economic considerations; the third criterion concerns policy choice and is as much (if not more) a matter of political economy or political science than economics, and his fourth criterion is essentially legal in nature. To the extent that the third and fourth criteria bite - that is, they narrow the set of allowable multilateral disciplines - then in Maskus's schema economic considerations alone cannot settle this important policy matter.

My next point is that Maskus's implied use of multilateral rules to foster the optimal policy choice from the global perspective is very much motivated by the economist's concern with economic efficiency and resource allocation. Distributional considerations, development considerations, legitimacy, other common values, etc., all of which were mentioned as important factors in deliberations in the Doha Round on the Singapore issues, are not the objectives being pursued in this schema.

Having said that, a focus on economic efficiency and resource allocation is broader than only considering the consequences of government policy for the market access enjoyed by trading partners. It is perfectly possible for a policy to create cross-border economic spillovers without it constricting market access. The successful prosecution and break-up of a global cartel by the competition enforcement agencies of the USA or the EC, which has happened often in the past 15 years, can raise the welfare of trading partners without having implications either way for market access. From a world welfare point of view, such prosecutions should be encouraged. The fact that only the likely harm within a jurisdiction is used as an important factor in determining the enforcement priorities of competition agencies suggests that some globally valuable prosecutions may not be pursued. A case for international collective action could be developed here without reference to market-access considerations. Such a case would be consistent with Maskus's mainstream economic principles, but, in the interests of completeness and balance, I acknowledge that it may still fall foul of the two non-economic criteria that he proposed.

The combined effect of the economic criteria described by Maskus is quite weak, in that they only exclude from multilateral-trade rule-making those policies which do not influence directly or indirectly international commercial flows, or, even if they do, have no adverse spillovers on any trading partner. I contend that the policy instruments identified by the proponents of the Singapore issues for binding multilateral disciplines would have passed these two economic criteria. More restrictive trade-facilitation measures tend to reduce imports from abroad, creating a direct spillover effect for those exporters not able to switch overseas markets costlessly. Restrictions on foreign investment can have immediate crossborder spillover effects on the profitability of foreign firms. Failure to enforce a national cartel law can make a jurisdiction a safe haven for organizing regional or worldwide cartels, creating adverse knock-on effects for the nation's trading partners. Evidence about the cartel's formation and organization can be stored in the safe haven without the risk of seizure and being sent to competition agencies abroad. Non-transparent public-procurement practices can deter potential foreign firms from bidding for state contracts. In sum, the two economic criteria advanced by Maskus - and recall that he believed he was summarizing mainstream economic opinion - would not have provided a basis for rejecting the launch of the Singapore issues at the Cancún Ministerial Conference.

Interestingly, when some trade economists have opposed the launch of negotiations on the Singapore issues, they have tended to point to non-economic considerations to justify their position. Whether they are qualified to make such claims in every instance is another matter, but I leave that concern to one side. For example, Lloyd (2005) objected to the creation of a 
multilateral competition authority ${ }^{22}$ on the grounds that the object of WTO law should be a WTO member and not a private party. This is essentially a legal argument concerning, in this case, the prerequisites for enforcing a proposed multilateral rule.

In contrast to Maskus (2002), Lloyd (2005) and Lawrence (2006) both appeal to the objectives specified in the Agreement Establishing The World Trade Organization to develop a distinct requirement that any new WTO rule (multilateral or plurilateral) should be consistent with those objectives. Consequently, both argue that additional WTO rules that reduce trade barriers, reduce discrimination in international commerce, and improve market access are consistent with the objectives of the WTO. Lawrence (2006) also notes that promoting development is another WTO objective. I have two comments to make about these suggestions. First, with respect to the requirement to reduce trade barriers etc., to the extent that this is a precondition then it will exclude forms of international cooperation that meet Maskus's first three principles; therefore, some initiatives to improve international resource allocation would not be admitted to the WTO. Care is needed at this point in the argument because, before condemning the narrowness of the requirement to reduce trade barriers, discrimination in international commerce, etc., one ought to consider whether the same initiative could not just as effectively be undertaken in some other international fora. If so, then the benefits to the world economy of the forms of international cooperation excluded from the WTO need not necessarily be lost.

Second, some proposals for international collective action may well meet Maskus's economics-related criteria, fail the requirement of reducing discrimination in international commerce, yet satisfy the requirement of promoting development. ${ }^{23}$ What should be done in this case? The difficulty arises from the fact that the WTO agreements contain more than one distinct objective. Worse, since promoting development is such an objective and development itself is often understood to be a multi-faceted phenomenon including both non-economic as well as economic components, then the boundaries of the WTO as defined by a development-promoting requirement may well be different from those associated with a requirement to reduce discrimination in international commerce. For these reasons, appeals to scripture (WTO agreements) are not going to take this particular debate forward very far.

A potential deficiency in the criteria proposed by Maskus is that they do not consider the political pre-requisites to support multilateral rule formation both nationally and within the WTO. For sure, Maskus's third criterion concerns the political-economy factors that account - from a global perspective - for sub-optimal national policy choice. Here, Wolfe (2007), from a political-science perspective, provides some useful guidance. In his 11 criteria for deciding whether to include matters in the WTO's Single Undertaking he includes 'it should be possible to negotiate a multilateral modality that allows for variable geometry and differentiation' (p. 19), 'negotiations must engage a transgovernmental network willing to see the WTO as a focal point for their work' (p. 19), and 'new rules must also engage a group of officials in each member who are able to see the relevance of the WTO' (p. 20). These three

\footnotetext{
${ }^{22}$ I will not dwell on the fact that the proponents of a multilateral framework on competition explicitly ruled out the creation of such an agency and confined their actual proposals to disciplines on national competition law or, where WTO members chose to cooperate in this fashion, regional competition law.

${ }^{23}$ The proposal by the EC that each WTO member enact and enforce a national cartel law could meet a requirement of promoting development because one of the forms of cartel is bid-rigging, where firms collude in the bids that they make for state contracts. Developing-country governments are the targets of bid-rigging as submissions and presentations at the OECD's Global Fora on Competition have shown. School construction projects in China, for example, have cost more than they should because of bid-rigging.
} 
requirements speak to the actors within and between WTO members who must, in Wolfe's view, support the negotiation of multilateral rules. I would note here the distinction between what should be, what is, and what is likely to be. Wolfe's three requirements seem more appropriate for judging what measures are likely to garner enough support to be included in the WTO. There could well be groups who, for whatever reasons, including the preservation of existing privileges, powers, or autonomy, do not support the negotiation of multilateral rules, even though an efficiency-based logic would suggest that such rules ought to be negotiated and implemented. I do not regard this as a logical quibble. Some of the strongest opposition to negotiating a multilateral framework on competition policy actually came from the long-established competition agencies and the national and international competition legal bar. In terms of what happened to that particular Singapore issue, the factors identified in Wolfe's analysis are useful in that they shed light on the matter at hand. However, I would be careful about using these three of Wolfe's criteria for purely normative purposes.

Perhaps appropriately, given the subject matter of this paper and his close involvement in the deliberations over the Singapore issues, the last aspects of the 'wrong institution' hypothesis to be discussed here refer to the writings of Pascal Lamy. Contrasting Maskus's four criteria with the discussion in Lamy (2004) is both thought-provoking and instructive. I start by noting that Lamy argued that there were fundamental lessons to be learned from the collapse of the Cancún Ministerial Conference and that those lessons related to the very purpose of the WTO and the proper form of international economic governance more generally. Given the focus of this paper, one of Lamy's most important arguments is that economic efficiency is given far too much weight in discussions on the design of international economic governance more generally and, by implication, of the WTO (p. 11). In his view, 'shared values' and 'legitimacy' are also important 'functions' of international economic governance (p. 12). Lamy, like Maskus, then includes non-economic considerations in determining the boundaries of the WTO. Where the two views appear to be at odds is over what those non-economic criteria should be. The extent of any tension would appear to turn in large part on what constitute 'shared values' and 'legitimacy' and whether those two considerations are additional criteria to be met by proposals for multilateral rules, or whether they are substitutes for the efficiency-related criteria that economists put so much weight on.

In addition to their possible efficiency-enhancing effects mentioned earlier, plausible arguments could be advanced which link the various proposals for binding multilateral disciplines on the Singapore issues to certain interpretations of the 'shared values' and 'legitimacy' functions that Lamy sees for the WTO. If, for example, promoting and preserving transparency were a shared value of the WTO membership, then proposals to enhance the transparency in government procurement policies align nicely with that function. Moreover, if it is argued that the legitimacy of international market integration depends on the distribution of the gains from international commerce, then, to the extent that greater inter-firm rivalry results in a broader distribution of benefits across customers and producers, multilateral disciplines that encourage national and international measures to tackle anti-competitive practices can be reconciled with the legitimacy function of the WTO. Much turns on precisely what one wants the WTO to achieve. Indeed, given the emphasis placed by many on promoting development in the Doha Round and by others who prefer to stick to market-opening and liberalization, it might be worth considering whether disagreements over matters as fundamental as what its members really want the WTO to accomplish implicitly underlie the discord and tortuous negotiations witnessed over the past 6 years. If this is the case, then the disagreements over the Singapore issues, controversial 
matters such as Special and Differential Treatment, etc., may just be manifestations of a more serious rupture.

The purpose of this sub-section has been to highlight the lack of any agreed guidelines as to what policy instruments should be included within the boundaries of the WTO. It is not that analysts have shied away from devising such guidelines, rather that they are unsatisfactory in some respects or are at odds with one another. The notion that proposals for additional multilateral rules on the Singapore issues fell foul of some generally accepted principles for what should or should not be included in the WTO is incorrect.

\section{Concluding remarks}

There were sharp disagreements between WTO members on the treatment of the four Singapore issues at the Cancún Ministerial Conference. The goal of this paper is to understand why this disagreement arose, bearing in mind that many factors may have contributed. In an attempt to specify, clarify, and examine the importance of different potential causes I have identified five distinct hypotheses: the five 'wrongs' being 'wrong tactics', 'wrong proponent', 'wrong timing', 'wrong proposals', and 'wrong institution'. Understanding the relative importance of each hypothesis, as well as the merits of the criticisms levelled against the Singapore issues, may well shed light not just on the fate of these issues in the Doha Round, but also on the prospects for including them in the WTO in the future.

Although criticisms of the Singapore issues associated with all five hypotheses can be found in the public record and literature on these matters, I would argue that the first three hypotheses have the greatest explanatory power. Tactical mis-steps by the European Commission, the legacy of the Uruguay Round, plus a willingness by poorer WTO members to stand up to both the European Commission and United States, for the most part account for the fate of the Singapore issues. Perceptions about the outcomes of the Uruguay Round emboldened many developing countries and analysts and contributed to the demise of three of these issues, even though I find the substance and the inferences drawn from the associated criticisms of the Uruguay Round wanting in many fundamental respects. Criticisms of the actual proposals advanced by the proponents of the Singapore issues and the argument that they should not be part of the WTO (the 'wrong institution' hypothesis) were certainly part of the rhetoric heard in the early years of the Doha Round, but I have serious doubts that these technocratic matters were ultimately that influential. A caveat here is that, in principle, senior trade policy-makers could have privately considered the details of these technocratic matters and decided on this basis to oppose the Singapore issues, but explained their opposition in very different terms. Once we know more about the internal deliberations of trade ministries during the Doha Round, we can revisit this subject matter; in the meantime I stick to the above assessment.

If this assessment is correct, then it does not rule out the eventual return, albeit almost certainly in a different form and potentially under different circumstances, of the Singapore issues. The WTO remains the leading reference point (as Lamy (2004) puts it) of international economic governance, not just because of the WTO's wide range of existing binding disciplines, but also because of its dispute-settlement mechanism. After being bloodied and bruised during the Doha Round, it would not be surprising if the EC and the USA refrained from advancing the next set of proposals for multilateral rules on some, or all, of the Singapore issues. This is not to say these two trading powers will not seek to include provisions on the Singapore issues in the free trade agreements (FTAs) that they negotiate. 
Indeed, the EC is proposing to do just that in a forthcoming set of FTA negotiations and both the EC and USA have sought such disciplines in the past in FTAs. Quite separately, the experience with provisions relating to the Singapore issues in FTAs could provide an important source of information and insights of potential relevance to future initiatives in the multilateral trading arena. Capitalizing on the proliferation of FTAs and their growing tendency to go 'behind the border' may call for some type of mechanism or initiative to keep track of these developments and to consider their implications for the efficacy, design, and implementation of multilateral trade rules in these areas. Augmenting the WTO's surveillance and analytical functions in this respect could eventually yield valuable insights for the entire WTO membership.

If future initiatives on the Singapore issues are less likely to come from the Western trading powers, then which WTO members could be their demandeurs? With their fastgrowing overseas interests, whether through trade or foreign direct investment, including cross-border mergers and acquisitions and the like, the emerging poles of the world trading system (specifically Brazil, China, India, and, upon its accession to the WTO, Russia) may well find that numerous behind-the-border measures of their trading partners, and not just those associated with the Singapore issues, have a greater adverse effect on their firms' and national interests than is currently recognized. ${ }^{24}$ Proposals for additional multilateral rules could well follow. As these proposals are unlikely to incorporate uncritically the standards of industrialized countries, any subsequent debate on such proposals may well avoid some of the development-related pitfalls that befell the four Singapore issues in the run-up to the Cancún Ministerial Conference.

The account of the fifth hypothesis ('wrong institution') also revealed a number of first-order matters that warrant further attention by scholars and trade-policy analysts in general. More work on refining sets of criteria for the inclusion of matters into the Single Undertaking of a multilateral trade round is certainly needed. We still do not have a compelling conception, let alone conceptions, of what should constitute the boundaries of the WTO. Without this we ought not to be surprised if long-standing grievances, geopolitical considerations, and tactics (perhaps unduly) influence the trajectory of the WTO! Thinking through what permutations of objectives and associated criteria might mean for the WTO's boundaries would be particularly instructive now that the WTO membership has added promoting development to its traditional goal of reducing discrimination in international commerce.

However, the discussion of the fifth hypothesis implies that there is a more fundamental task before international trade scholars, analysts, and diplomats: establishing precisely what the WTO's members want of it, or should want of it, would help clarify the objectives and functions of the WTO. Some prefer economic efficiency (or improved resource allocation) as the overriding objective; others put weight on matters such as enhancing legitimacy, advancing shared values, promoting development, and the like. The consequences of each objective, the relationship between objectives, as well as the coherence of any set of objectives could be explored further. Such inquiry would be of systemic value in its own right, as well as having implications for what should constitute the boundaries of the WTO. Finally, although the fate of the Singapore issues in the early years of the Doha Round did not turn explicitly on disagreements over these matters of the first order, should the central objectives and functions

\footnotetext{
${ }^{24}$ Further thoughts in this regard can be found in Evenett (2007), together with some statistics and quotations from leading policy-makers from some of the rising trading powers that suggest that officials are beginning to see that certain Singapore issues merit greater attention in their national trade policies.
} 
of the multilateral trading system be thoroughly examined in the years to come, then not only might we have a better sense of what the boundaries of the WTO could or should be, but the contents and prospects of future attempts to expand the remit of binding multilateral rules may be influenced as well. This is not to say that tactics, geopolitical considerations, timing, and the specifics of proposals for new multilateral rules will not matter; rather, that there is more room for deliberations on the changes in the scope of the WTO to be informed by a clearer conception of the very purpose of the multilateral trading system.

\section{References}

Ahmed, N. (2003), 'Cancún And Aftermath', Ministry of Commerce, Bangladesh.

Deardorff, A. V., and Stern, R. M. (1998), Measurement of Non-tariff Barriers, Ann Arbor, MI, University of Michigan Press.

Evenett, S. J. (2003a), 'A Study on Issues Relating to a Possible Multilateral Framework on Competition Policy', prepared for the World Trade Organization's Secretariat.

- (2003b), 'The Failure of the WTO Ministerial Meeting in Cancún: What Implications for Future Research on the World Trading System?', CESIfo Forum, Autumn, 1-17.

- (2007), 'EU Commercial Policy in a Multipolar Trading System', Review of European Economic Policy/Intereconomics, 42(3), 143-55.

- Hoekman, B. M. (2005), 'Government Procurement: Market Access, Transparency and Multilateral Trade Rules', European Journal of Political Economy, 21(1), 163-83.

Federal Trust (2003), 'Expanding WTO Rules? Should there be WTO Rules on Competition, Investment, Trade Facilitation, and Transparency in Government Procurement?', 5 June, London, Federal Trust for Education and Research.

Finger, J. M. (2007), 'Implementation and Imbalance: Dealing with Hangover from the Uruguay Round', Oxford Review of Economic Policy, 23(3), 440-60.

Hoekman, B. M. (2003), 'Cancún: Crisis or Catharsis?', note circulated at the Brookings-George Washington Trade Roundtable, 17 September.

- Newfarmer, R. (2003), 'After Cancún: Continuation or Collapse?', Trade Note, International Trade Department, Washington, DC, World Bank, 17 December.

Ismail, F. (2005), 'A Development Perspective on the WTO July 2005 General Council Decision', Journal of International Economic Law, 8(2), 377-402.

Khor, M. (2003), ‘An Analysis of the WTO's Fifth Ministerial Conference (Cancún, 10-14 September 2003)', Third World Network.

Kol, J., and Winters, L. A. (2004), 'The EU after Cancún: Can the Leopard Change its Spots?', European Foreign Affairs Review, 9, 1-25.

Lamy, P. (2003), 'Commissioner Lamy's Speech at the EP — Result on the WTO Ministerial Conference in Cancún', 24 September.

- (2004), 'Europe and the Future of Economic Governance', Journal of Common Market Studies, 42(1), $5-21$.

Lawrence, R. Z. (2006), 'Rulemaking Amidst Growing Diversity: A Club-of-Clubs Approach to WTO Reform and New Issue Selection', Journal of International Economic Law, 9(4), 823-35.

Lloyd, P. (2005), 'When should New Areas be Added to the WTO?', World Trade Review, 4(2), $273-93$.

Maskus, K. E. (2002), 'Regulatory Standards in the WTO: Comparing Intellectual Property Rights with Competition Policy, Environmental Protection, and Core Labour Standards', World Trade Review, 1(2), $135-52$.

Sandrey, R. (2006), 'WTO and the Singapore Issues', Tralac Working Paper No. 18/2006, November.

SECO and Evenett, S. J. (eds) (2003), The Singapore Issues and the World Trading System: The Road to Cancún and Beyond, Swiss State Secretariat for Economic Affairs, June.

White \& Case (2003), 'WTO Talks Collapse in Cancún: A Splash of Cold Water, or Dead in the Water?', Special Report on the WTO Cancún Ministerial, No. 6, 16 September, New York, White \& Case LLP. 
Wolfe, R. (2007), 'Can the Trading System be Governed? Institutional Implications of the WTO's Suspended Animation', forthcoming as a Centre for International Governance Innovation Working Paper, Waterloo, Canada, 24 May.

Woolcock, S. (2003), 'The Singapore Issues in Cancún: A Failed Negotiation Ploy or a Litmus Test for Global Governance?', Review of European Economic Policy/Intereconomics, 38(5), 249-55. 